\title{
Globalization and Economic Relations Perspective of Albania - Kosovo
}

\author{
MS. Elona Shahini (Shehu) \\ Lecturet at Mediterranean University of Albania \\ elonashahini@umsh.edu.al \\ Dr.Sokol Pacukaj \\ Lecturet at "A.Moisiu" University, Durrës \\ sokolpacukaj@gmail.com \\ Prof. Albert Qarri \\ Rector at "Ismail Qemali" University, Vlorë \\ albertqarri@yahoo.com
}

Doi:10.5901/ajis.2014.v3n4p161

\section{Abstract}

Relations between Albania and Kosovo in recent years have intensified significantly. This is seen in the volume of economic cooperation agreements, political and social, in joint meetings between the Governments of the two countries, the volume of trade exchanges, the export-import, the volume of mutual investments etc. Kosovo after 2000 and especially after 2008, the year of the declaration of independence recognized satisfactory growth rates of the Economic. In the years 2009-2012 there were no obvious consequences to the economic downturn as a result of the global recession. Kosovo in terms of GDP ranks 146 th (CIA) in the world. While GDP per capita according to the CIA ranks 104 out of 187 countries worldwide. In the paper are analyzed the main branches in February Kosovo economy such as agriculture, industry and services. We have also provided some of the dynamics of the main macroeconomic indicators. Albanian economy from 2009 onwards has been positive indicators of GDP but the downward trend, the inflation rate has been stabilized according to CB's forecasts and unemployment has recorded high levels, ranging from 12.8-13.5\%. Regarding GDP, Albania is ranked 125 (CIA) in the world. GDP per capita, according to the CIA, Albania is ranked 100. Has a higher GDP than Kosovo, Macedonia and Montenegro. For Albanian we have given a summary of economic indicators and analyzed the dynamics of the main macroeconomic indicators. Following are analyzed economic relations between Albania and Kosovo. Macroeconomic indicators are presented to show their condition. Further consideration is given to the possibility of proliferation and deepening of economic relations.In the end we made a summary of the issues addressed in the paper and give some recommendations that are to be taken into consideration by the Governments of the two countries.

Keywords: Inflation, unemployment, Gross Domestic Product (GDP), economic growth, trade balance, deficit, fiscal policy, monetary policy, economic relations, open economy, etc.

\section{A Look of Kosovo and Albanian Economy}

\subsection{Kosovo's economy}

Kosovo is one of the youngest countries in the world. It derives from Serbia in 1999. It declared independence on 17 February 2008. Secession from Serbia and the creation of a dependent state without the opportunity for a reversal of economic and financial model followed up in those years. From a centralized state has sought and intends to return to the open market economy based on private ownership of the means of production. Kosovo has made changes in legislation introducing and adapting modern European legislation. The economic model is selected mixed economy based on private property and state property. Financial model is selected bank-stock. Kosovo has two layered banking system. In Kosovo operate 10 commercial banks that carry out a range of services including loans, guarantees, current accounts, savings accounts, time deposits, transfers within and outside the country as well as storage services for items of value. Commercial banks are privately owned. The banking sector is estimated as the sector with the best performance in the economy. The currency in circulation is Euro. Kosovo's economy is in the process of privatization of the economy. 
Privatizations so far have proved successful. Country Kosovo borders Serbia, Montenegro, Albania and Macedonia.

Place the item in the world for

Overview of Some Key Macroeconomic Indicators ${ }^{1}$

Currency

Fiscal Year

No. Population

Area

GDP

GDP growth rate

GDP per person

GDP - the division into sectors

The unemployment rate of about $30.9 \%$

Inflation rate
143 GDP (PPP, 2012)4

Euro $(€)$

Calendar Year

1.8 million

$10,908 \mathrm{~km}^{2}$

5,02 billion $€(2012)$

$2.9 \%(2012)$

$€ 2,750(2012)$

agriculture $20 \%$, industry $20 \%$, services $60 \%$

$2.5 \%(2012)$

\section{Population below Poverty Line from 30 to $45 \%{ }^{2}$}

$\begin{array}{lr}\text { Gini Coefficient } & 30(\text { FY 2005-2006) } \\ \text { Workforce } & 880,000(2011) \\ \text { Unemployment } & 30.9 \%(2013)^{5}\end{array}$

The main industries; mineral industry, construction materials, base metals, leather, machinery, equipment, food and beverages, textiles etc.

Ease of doing business in the country of

Foreign direct investment - FDI

Exports

Imports

Natural resources

Gross external debt
232.0 million 276,100 million $€(2012)$

2.507 billion $€(2012)$

lignite, zinc, lead, ferro-nickel and fertile agricultural land.

\$326 million (31 December 2012)
Public debt is

\section{Public Finances}

Revenues

Costs
$5.5 \%$ of GDP (2011)

$\$ 1740000000(2011)$

$\$ 2060000000(2011)$

\begin{tabular}{|c|c|c|c|c|c|}
\hline \multicolumn{6}{|c|}{ Dynamics of Some Key Macroeconomic Indicators 3} \\
\hline Description & 2008 & 2009 & 2010 & 2011 & 2012 \\
\hline GDP (in millions of euros) & $3,710.7$ & $4,077.0$ & $4,136.5$ & $4,486.0$ & $4,895.5$ \\
\hline Prices (annual average) & $9.4 \%$ & $-2.4 \%$ & $3.5 \%$ & $7.3 \%$ & $2.5 \%$ \\
\hline Prices (annual) & $0.5 \%$ & $0.1 \%$ & $6.6 \%$ & $3.6 \%$ & $3.7 \%$ \\
\hline \multicolumn{6}{|c|}{ Extemal sector (in million euros) } \\
\hline Current Account & -460.9 & -374.2 & -515.7 & -658.4 & -380.3 \\
\hline $\begin{array}{l}\text { of which : imports of goods } \\
\text { of which : remittances in }\end{array}$ & s $-1,649.7$ & $-1,651.7$ & $-1,752.1$ & $-2,059.0$ & $-2,073.0$ \\
\hline Kosovo & 608.7 & 585.7 & 584.3 & 584.8 & 605.1 \\
\hline FDI in Kosovo & 341.5 & 280.9 & 331.1 & 378.9 & 229.1 \\
\hline
\end{tabular}

\subsubsection{Some important sectors of the economy of Kosovo}

The Energy and The mines-Kosovo has abundant underground resources, with 14,700 million tons, it ranks fifth in the world for coal reserves from which it also produces the largest amount of electricity. Kosovo in 2008 produced 4,738 billion kWh and has spent 5,156 billion kw/h of electricity.

The reserves of this mineral, which is used as the main source of energy production in Kosovo, estimated to last for 650 years, with the pace of current extraction.

Lignite reserves are distributed in the basin of Dukagjin and Drenica, but the extraction of the mineral is currently

${ }^{1}$ CIA World Factbook https:/Ŵŵw. cia.gov/library/publications/the-ŵorld-factbook/geos/kv.htmIPAGE LAST UPDATED ON JANUARY 27, 2014.

2 "Results of the Kosovo 2012 Labour Force Survey". Kosovo Agency of Statistics. September 2013. p. 9. Retrieved 29 October 2013.

${ }^{3}$ BQK.Buletini Mujor Statistikor. Shkurt 2014/Nr. 150 
limited to the Kosovo basin. Besides Kosovo lignite is also rich in zinc, lead, gold, cadmium and bismuth, bauxite, nickel, etc.. Culture lignite mining dates back to Roman times, modern extraction of minerals in Kosovo began in 1930s with the establishment of Trepca Complex.

Agriculture and Livestock-Kosovo is rich in agricultural land, 53 percent of the total arable land. Currently, agriculture contributes only 19 percent of the total AWU - in and 15 percent of export value. Food processing in Kosovo has traditionally been led by social enterprises, whereas today they are inactive; new private companies have begun operating in this field. Most of these companies are small and are not able to cover most of the demands in the market. Investing in these companies, the provision of new management techniques could regenerate the expropriation agroindustry in Kosovo, to the point that could be competitive in international markets.

Vineyards-growth of grape and wine production is an old tradition in Kosovo. During the golden years of the wine industry in Orahovac only had a production capacity of up to 50 million liters per year. In 1989, the export of Orahovac wine has reached 40 million liters, which are distributed mainly in the German market. After the privatization of part of the vineyard, and the wine factory in Orahovac, has managed to cover a good portion of the local market has also found success in the market segment of international, especially European.

Construction-In recent years the construction industry has become one of the most important sectors in the economy of Kosovo. This sector continues to be a great economic potential for Kosovo, taking into account the need for the construction of new settlements and road infrastructure. Government of Kosovo has decided to aim to link the country with the most important corridors in Macedonia, Albania and Serbia.

Textile industry-textile was the second largest sector in Kosovo, while at the peak of its development, 15 social enterprises textile production employed more than 1,000 people and achieved sales up to 35 million euros. Despite recent developments in the region, who have broken trade links, the analysis indicate that 55 to 65 million euros can be accessed from the export restitution if these connections. In this sector has plenty of room for investors to Kosovo once again produce finished clothing from textile produced in the region.

Tourism-Tourism potential is closely related to Kosovo geographical position, surrounded on all sides by mountains, and in the center of the Balkans, it has potential for winter tourism.

Mountains in the south of Kosovo, resorts Brezovica and Sharr Mountains are good opportunities and interesting for investors. Currently Brezovica resort has three hotels, two restaurants and nine ski lifts that are currently socially owned. Besides Brezovica, other mountains are used for winter tourism are located in western Kosovo. It is thought that this tourist location has the potential to receive up to 30,000 visitors tour. The potential of this region have started to use small companies that have built private Bogaj village.

\subsection{Albanian economy}

Albania's economy has undergone a transformation from its communist past in an open economy and free market in the early 1990s. Even though the country is rich in natural resources, the economy is based mainly on agriculture, food processing, lumber, oil, cement, chemicals, mining, basic metals, hydropower, tourism, textile industry, in remittances and informal economy.

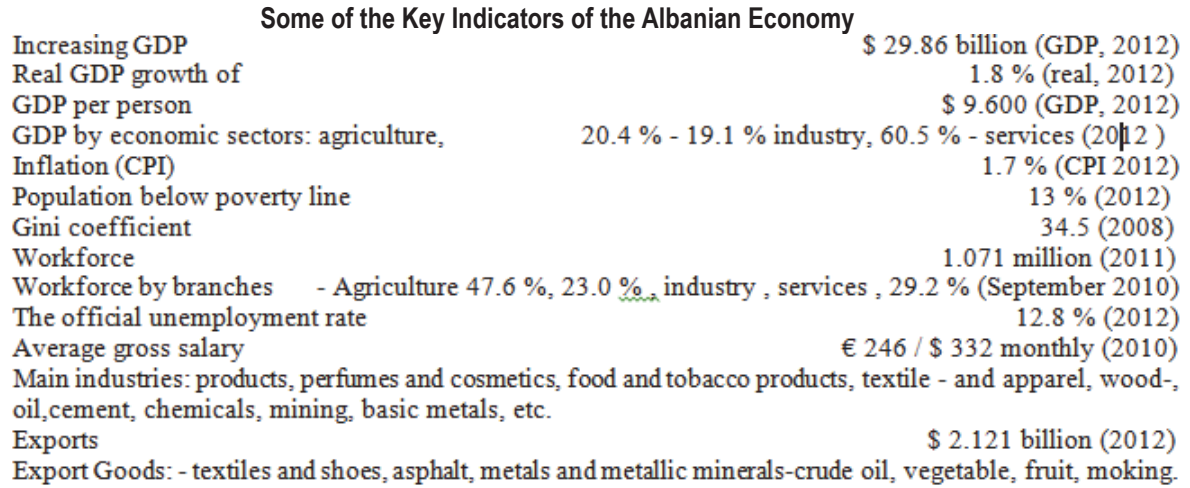




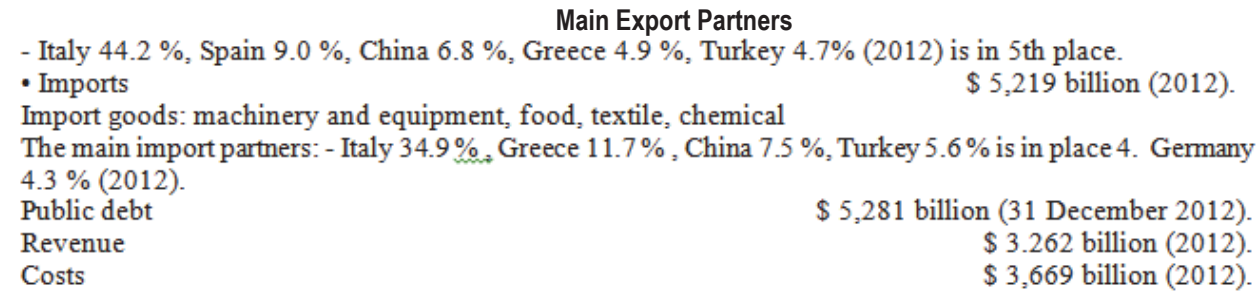

\subsubsection{Areas where Albania performed}

Albania has achievements in the field of legislation in the area of institution building in the privatization process, the degree of opening to the outside world, in international relations and in the financial sector.

In Albania after 90 years created a contemporary new legislation, west, in accordance with the principles of the market economy in all fields, political, social, legal, economic, financial, commercial, etc. The new legislation is based on the fundamental law of the state, the Constitution of the Republic of Albania, is a contemporary legislation and fully harmonized with the standards of legislation European Union countries.

Albanian Parliament from 1997-2012 have since adopted more than 2,242 laws. Among which are: Law on Land, the Law on excise duties, VAT Law, the Law on compensation for farmers, the Law on Income Tax, Internal Audit in the Public Sector, Law on Tax Procedures in the Republic of Albania, etc..

Government of Albania is receiving hundreds of laws, decisions and support service economy. Among them mention DECISION No.4 dated 07.01.2010 FOR APPROVAL OF macroeconomic and fiscal framework, 2011-2013.

Have been important reforms in the field of pre- 9 -year secondary education and university. System introduced by 8 year old 9 year old that has been, is applied Bologna bachelor-master system $(3+2)$. In Albania there are 59 higher education institutions.

In the field of health, despite ubsenteeism and undesirable phenomena of corruption as it have made significant progress. Liberalized market in the field of medical education.

In the field of transport undertaken a series of internal reforms and public transportation is almost completely privatized. After undertaking legal reforms and creation of appropriate institutions privatization process was instrumental in defining the type of economic model that would follow Albania in these years of transition. Just what was intended, what objects will had, what objectives will achieve, what way would you implement them, as would have been realized, would all sectors privatized, which would be legal, were some of the problems identified model Albanian government applied these 20 years of transition.

Private property has become dominant in our economy where over $90 \%$ of private property and is currently providing about $80 \%$ of GDP and $85 \%$ of employees. Privatization periods were:

First Period 1993-1999

Second period $2000-2012$

Albania is since and cooperates with all international economic and financial institutions (WB, WTO, IMF, EBRD, GTZ, UNDP, etc.). Has economic relations with over 100 countries. Free trade agreements with Albania applied are:

- $\quad$ SAA

- $\quad$ Free Trade Agreement of the Central Europe (CEFTA)

- Free Trade Agreement with Turkey

- Albania and Programme of Generalized System of Preferences (GSP) of the United States.

In Albania today operate 16 commercial banks with foreign capital and domestic, wholly privat.

\subsubsection{The main macroeconomic indicators}

Albanian economy after 1990 until today has increased and economic decline. After 2007 it has increased GDP despite its pace. In the 2009-2013 global recession GDP growth rates have been in decline. So in 2013 it had risen only $0.44 \%$. Indicator of inflation has been stabilized while the unemployment rate has been and remains a problem. February we are providing these trguesve dynamics. 
Tabela 1: The index of GDP, Inflation and unemployment for the years 2008-2013 in Albania

\begin{tabular}{|l|c|c|c|c|c|c|}
\hline \multicolumn{1}{|c|}{ Denominate } & $\mathbf{2 0 0 8}$ & $\mathbf{2 0 0 9}$ & $\mathbf{2 0 1 0}$ & $\mathbf{2 0 1 1}$ & $\mathbf{2 0 1 2}$ & $\mathbf{2 0 1 3}$ \\
\hline GDP\% & 7.5 & 3.3 & 3.8 & 3.1 & 1.6 & 0.44 \\
\hline Inflation\% & 2.2 & 3.7 & 3.4 & 1.7 & 1.6 & 1.7 \\
\hline Unemployment \% & 12.7 & 13.6 & 13.5 & 13.2 & 12.8 & 12.8 \\
\hline
\end{tabular}

Grafiku 1: Index of GDP, Inflation and unemployment.

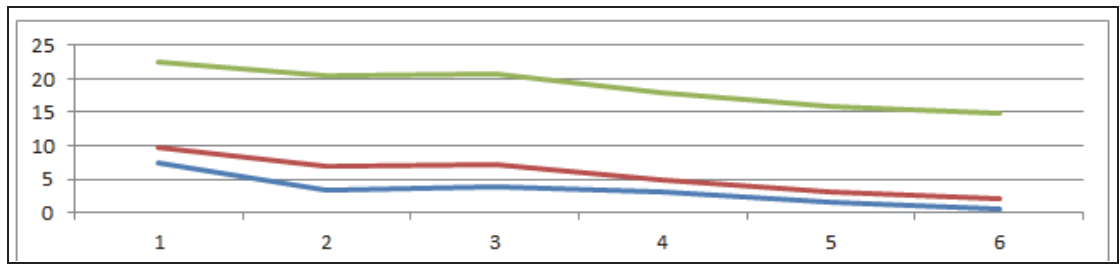

\subsubsection{GDP}

Albania 1997 excluding all other years there has been economic growth. In 2008 marked the largest increase in the last 10 years by $7.5 \%$. The global recession affected the economy doing this consistently fall swing. So 2013 has lower growth after the onset of the global recession. The services sector is the most developed and captures over $50 \%$ of GDP. The weight of the agricultural sector has fallen by $19 \%$, while increased weight of the construction sector. And in Albania are creating investment opportunities in tourism, exploitation and processing of subterranean water in agriculture, infrastructure, etc.

\subsubsection{Inflation}

The inflation rate is a leading indicator that has been consistently implemented by the Central Bank forecasts $3 \pm 1 \%$. The main reason of the performance of this indicator is that it generally depends on imported inflation and non- monetary terms.

\subsubsection{Unemployment}

It is characteristic that the number of employees by the year 2009 there has been a change but it was 142 thousand. The unemployment rate has changed due to fluctuations in the voice "within the working age" and because of migration. V In general, these impacts rejmë respective groups. Employees in the public sector have not changed in number to affect the unemployment rate. In the non-agricultural private sector have increased slightly in the last year.The agricultural sector is identified as the sector saw all those in the countryside are regarded as self employed but in fact none of them shed social security contributions. Actual growth in Albania for our judgment finds its expression in the unemployment rate, if we increase the employees then have the growth.

\section{Existing Relations between Kosovo and Albania}

How is economically focused Albania- Kosovo relations The greatest interest has been under economic indicators of Albanian entrepreneurs have moved towards Kosovo, but that still remains in considerable numbers hardly how have entered the market and how they can be active there. According to a survey conducted by an Albanian institution of higher education, which is based on data from the World Bank and official institutions of the two countries, to provide more realistic data, said that 2010 had the largest increase Kosovo Albanian investment.

In the Declaration of Independence was recorded 92 businesses, a year later two less, while the largest increase was recorded in 2010, when 145 registered businesses, on 2011-106 businesses, and in July 2012 to 68 businesses. In this way the total goes to 502 businesses, businesses with 2,190 employees, with a total capital of 59,781,835 euros. 
However, these figures do not talk much about the size and quality of the business, as 149 of them have zero capital, by identifying the Business Registration Agency. Meanwhile, ten companies commit capital 53,187,866 euros, or 98.9 percent of capital that all companies operating from Albania to Kosovo. For the activity, commercial enterprises dominate. There are a total of 139 such, with a capital of 2,272,531 euros and 398 employees. Also operating in this market for 11 subjects who have gambling activity and gambling, with 89 employees.

\subsection{Kosovo into Albania}

If Kosovo and Albanian has a number of undertakings that although the stated capital zero, from Kosovo to Albania movement is more rigid again. The number of businesses operating in Albania Kosovo is smaller, just 386 businesses. Their structure is not as good as they are dominated by small businesses. According to data from the Albanian authorities-197 entities have the status of limited liability companies, 180 are natural persons, while nine are joint stock companies.

\subsection{Economic presence in Albania and Kosovo and Albanian economy in Kosovo}

\subsubsection{First affecting exports and imports.}

Economic relations between Kosovo and Albania are centered on the exchange of goods, which, by its structure, more poor offer reflects both countries, rather than a large variety, or high share of final products.

Starting in 2000 until the end of June 2012, commercial exchanges, mainly metals dominate. Kosovo exports iron waste (scrap), as well as a small amount of steel pipes, while imports iron construction.

During this period, Albania, Kosovo exported goods worth more than 136 million euros, while imported nearly three times more-about 386 million euros. When the export is in question, noted that the large volume that had happened in 2000close to 3.4 million euros, not exceeding five years, so until 2005. This is more a result of lack of supply, but weak connections between the economies of both countries. Meanwhile, other years export has increased continuously. Furthermore, it gave impulse building Durres-Kukes-Morine, followed by a segment in the Kosovo.

On the other hand, imports grew at a faster pace. Of the four million respectively in 2002, at the end of 2011 it amounted to nearly 92 million. The largest increase occurred after the construction of the highway, from 40 million euros when it goes over 61 million euros. Import marked change in the structure and amount of the increase in weight. According to KC, until June of 2012, there are 56 types of imported items with a total weight of 70.7 thousand kilograms. Meanwhile, in the year 2011-62 imported items from Albania had total weight of 467.6 thousand kilograms. Kosovo is not a huge market for the Albanian economy, the exchange of goods since it has a small participation. In 2007, the total export of Kosovo took part 4.8 percent, while in 2011 to 7.4 percent. Meanwhile, the import share of Kosovo is very small: in 2007 was 0.6 percent, whereas in 2011 to 0.8 percent.

From the point of export-import data between Albania and Kosovo in recent years have shown a marked increase. So are significantly increased exports food products to Albania occupying Kosovo in 2010, $8.9 \%$ of total exports. Increased exports from Albania to Kosovo in terms of construction materials such as bricks and cement. Kosovo market is enjoyable for the Albanian business, because it is without spending a lot on both sides, as well as transport costs in their price level. Therefore we say that given the data Kosovo economy has helped Albanian exports and imports.

Graphic 2: Exports to Kosovo: Falling for the firs time since 2009

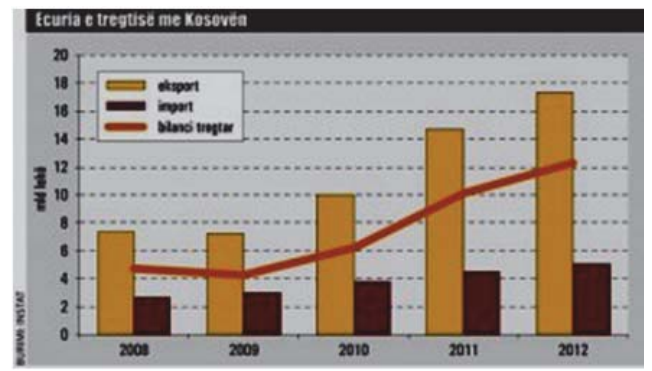


Economic relations between the two markets have been rising speaking. Official trade figures speak volumes for increased trade, at least until the end of 2012. According to the Institute of Statistics, Kosovo trade volume grew 3\% in 2012, reaching 17.4 billion. Record growth rates as imports and exports to this market.

By this time, the performance is good. But the weight of this trade, does not justify the fraternal relations that governments of both countries claim. According to INSTAT, in our exports overseas, Kosovo occupies only $8 \%$ of them. In fact, preliminary data of 2013 show a wince trade with Kosovo, as the trade volume (official data for 11 months) was the same as a year ago, 21 billion.

Table 2: Kosovo's main partners in the export and import in 2012

\begin{tabular}{lcccc}
\multicolumn{1}{c}{ Countries } & Export (000) $€$ & Total Partecipance & Import (000) $€$ & Total Partecipance \\
Italy & 71.351 & 25.8 & 213.469 & 8.5 \\
Albania & 40.180 & 14.6 & 110.528 & 4.4 \\
Macedonia & 26.376 & 9.6 & 287.739 & 11.5 \\
switzerland & 15.133 & 5.5 & 22.664 & 0.9 \\
Germany & 14.995 & 5.4 & 304.195 & 12.1 \\
Serbia & 14.968 & 5.4 & 278.388 & 11.1 \\
Turky & 11.380 & 4.1 & 199.881 & 8.0 \\
China & 3.266 & 1.2 & 159.651 & 6.4 \\
Total & 276.100 & 71.6 & 2.507 .609 & 62.9
\end{tabular}

The figures show the irrefutable fact that barriers give the effect of their governments. During the summer of 2013, the Kosovo government moved customs clearance points creating problems for Albanian exporters. Increased costs caused export of building materials (mainly brick tiles) almost completely blocked. Estimated to be exactly the period of August, which made our exports to Kosovo to go down for the first time since 2009. According to INSTAT, the value of these exports fell $7 \%$, while total exports rose nearly $16 \%$. In the same period, imports from Kosovo increased by $17 \%$. In total, our trade with Kosovo is as only $3.5 \%$ of our total foreign trade exchanges.

$7 \%$ of the total weight of Kosovo's exports

Graphic 3: 3.5\% share of the total trade our Kosovo

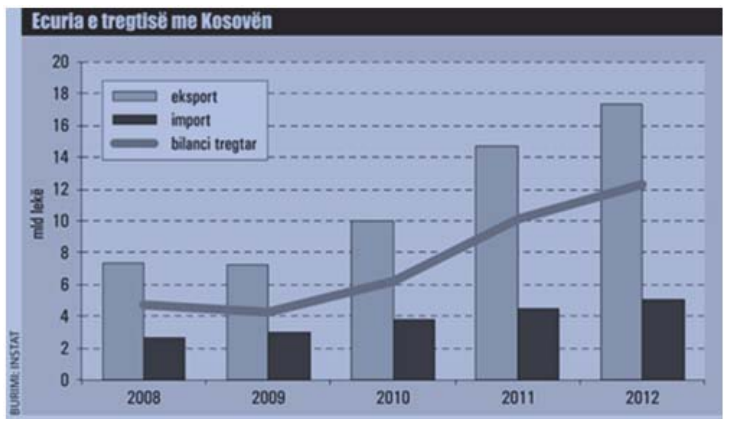

Below we give weight to the Kosovo Albanian exports to total exports in relation to Albania:

Exports: 276,100 million $€(2012)$

Main export partners: Italy (25.8 \%), Albania (14.6\%), Macedonia (9.6 \%), Switzerland (5.5\%)

Germany (5.4\%), Serbia (5.4\%), Turkey (4.1\%), China (1.2\%)

Goods exported: processed goods (56 \%), raw materials (25\%), food and live animals $6 \%, 4 \%$ fuel, machinery

and transport equipment (3\%), etc.

Imports: 2.507 billion $€(2012)$

The main import partners: Germany (12.1\%), Macedonia (11.5\%), Serbia (11.1\%), Italy (8.5\%),

Turkey (8.0\%), China (6.4\%), Albania (4.4\%), Switzerland (0.9\%). 
Imported goods: machinery and transport equipment (21\%), manufactured goods (20\%), fuel (16\%), ood and live animals (16\%), chemicals (10\%) etc.

Graphic 4: Export-Import of Albania and Kosovo 2003-2013

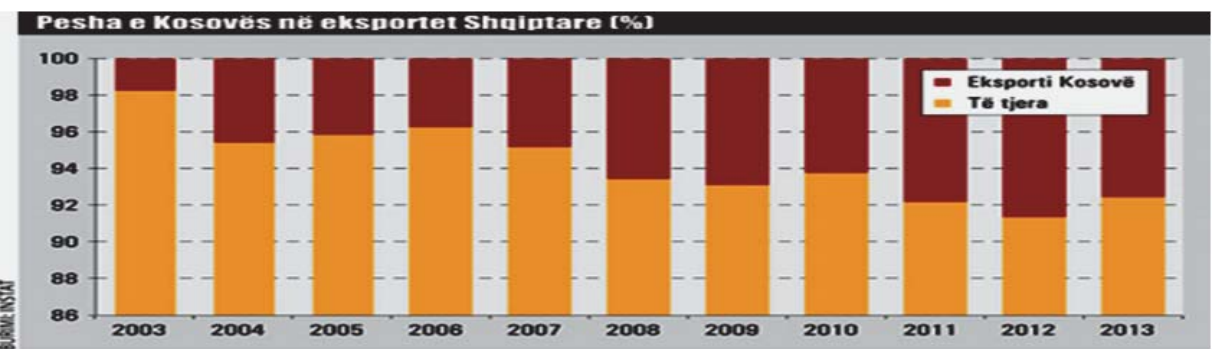

\subsubsection{Second, investments in mutual influence.}

Mutual investments, Kosovo is not on the FDI in Albania. Although Albania is present with investments in Kosovo, the latter does not appear in reports for FDI in Albania. There have been several attempts to penetrate Kosovo businesses in Albania, especially in catering and tourism, but these initiatives are smal. If listing the reasons why this lack Kosovo capital investment in our country, will support somebody come out great communication and establishing fiscal barriers, time and again, from one country from another. Although policymakers of both countries have trumpeted forcibly removing these barriers, even at peak production of various products is the imposition of customs first. But the environment and doing business in trouble placing parties, compounded by lack of supply and attractive from both countries. No mirrors. The number of state companies concerned in Kosovo.

Table 3: The number of companies in each country in Kosovo 2008-2012

\begin{tabular}{|l|c|c|c|c|c|}
\hline \multicolumn{1}{|c|}{ Countries } & $\mathbf{2 0 0 8}$ & $\mathbf{2 0 0 9}$ & $\mathbf{2 0 1 0}$ & $\mathbf{2 0 1 1}$ & $\mathbf{2 0 1 2}$ \\
\hline Albania & 65 & 85 & 109 & 89 & 78 \\
\hline Turkey & 62 & 72 & 75 & 77 & 78 \\
\hline Macedonia & 58 & 70 & 69 & 42 & 47 \\
\hline Croatia & 10 & 20 & 96 & 21 & 16 \\
\hline Slovenia & 21 & 19 & 23 & 24 & 17 \\
\hline Serbia & 21 & 23 & 24 & 18 & 15 \\
\hline Bulgaria & 11 & 16 & 22 & 18 & 6 \\
\hline \multicolumn{1}{|c|}{ Total } & $\mathbf{2 6 1}$ & $\mathbf{3 3 1}$ & $\mathbf{4 4 9}$ & $\mathbf{3 1 1}$ & $\mathbf{2 7 3}$ \\
\hline
\end{tabular}

Market opening Albanian and Kosovo made to penetrate business in Albania. So from Kosovo have direct investments and indirect investments. Kosovo businesses as well as businesses invest in Albania Macedonian buying or building a series of bar - restaurants in the Albanian coast.

Kosovo Albanian Investments, one of the last Immediately after the declaration of independence, Kosovo market was no interest from the Albanian entrepreneurs. Businesses that arrived first were those services:

bank insurance company, followed by fuel trading companies. A developing country like Kosovo would be" eager" for construction, and it can not go unnoticed by Albanian builders. But today, when he made five years from the declaration of independence, it seems that other entrepreneurs have moved faster to "arrive" in the Kosovo market. Based on the latest report of the Central Bank of Kosovo (CBK), foreign investment in Kosovo reach a total of nearly 1.4 billion euros. In the distribution of this amount between investor countries, Albania is among the latter. As seen from the graph, the Albanian investments made in private, there are about 100 million euros, slightly more than the Dutch investments. According to the bank, the main investors in Kosovo are Germans and Slovenians. 
Graphic 5: Foreign investments in Kosovo by country

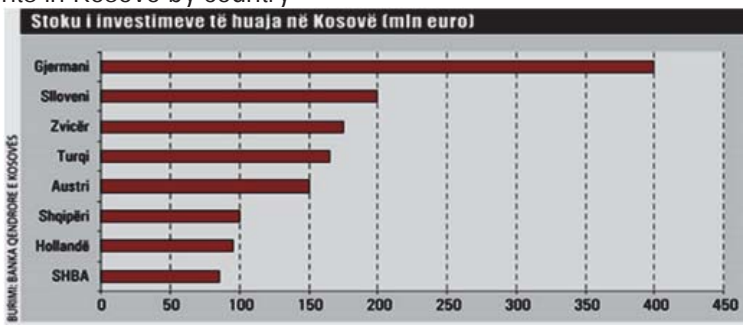

\subsubsection{Third, the impact on employment and border trade.}

It is important to note that part of the border population work as well there thence border depending on the respective professions and specialties. Likewise, there are everyday purchases small quantities of goods of wide consumption, food or clothing from both wings citizens, goods which are not recorded in customs. These are everyday regardless of quantity and as such have an impact on the lives of border areas. It is important to emphasize that in border areas such as Macedonia and the Kosovo Albanian lek freely used because it can be converted into dinars or euros at any moment. This is an advantage to the growth of this trade cross border.

\subsubsection{Fourth, the impact on tourism.}

Kosovo border every year and spend over a million people a part of which transit and tourism or a different job. Tourism is pronounced movement in the summer. European economic slowdown has not had much impact on the growth of people who have come for tourism from Kosovo, because this security sources of income from Kosovo have not changed much. Are those that have been before 2005.

During 2009, the number of tourists visiting Albania amounted to 3,050,828. This represents an increase of 35 percent compared to 2008, a clear indication of strong growth created by improvements in infrastructure and business requirements to support the tourism industry in this country. ${ }^{4}$

The UNDP data show that last year 55 percent of visitors were 914.046 Albanians from Kosovo, Macedonia and Montenegro. Although there is an increase of tourists from other countries, income from this industry figures remain low, with only 3.8 per cent of GDP. National History Museum "George Galway" is visited by 83 thousand tourists from around the world, ranking in first place among the most visited museums in the country. ${ }^{5}$ Of the total number of tourists, Panorama reported, 984,038 of them were foreigners and 1,105,500 were residents of other countries of Albanian descent. The latter, according to the World Tourism Organization, considered as tourists. ${ }^{6}$

\subsubsection{Fifth, the impact on education and culture.}

Many students from different regions of Kosovo Albanian Universities continue lessons in Kukes and Peshkopi and many students continue their studies in schools Albanian Gjakova and Prizren. Their movement is accompanied by the movement of money, so they have an impact on the integration of the economies of both sides of the border which is in mutual interest.

\subsection{Trade relations between Kosovo and Albania}

In recent years, the issue of trade relations between Kosovo and Albania is attracting great attention; especially the fact that they have started to identify the growth potential of this cooperation. Creating favorable conditions by institutions along with increased export potential of enterprises on both sides, and coupled with good relations rooted in common history, can play a vital role in improving trade relations between the two countries.

\footnotetext{
${ }^{4}$ Tourism development in Albania

${ }^{5}$ DR Newspaper

${ }^{6}$ Albania travellers
} 
Albania is the second partner of Kosovo's most important in terms of exports. Exports to Albania represent about 10 percent of total exports. But we must consider that in view of the value of these exports are very small. Conversely imports are two times larger than exports, however, compared with other regional vendettas, they remain much smaller. In terms of imports, Albania remains the only partner of eight, after Macedonia, Germany, Serbia, Turkey, China, Italy and Greece.

Kosovo and Albania should rush to increase their export potential and to create mechanisms to establish commercial relations between enterprises to facilitate the exchange. Improving road infrastructure is one factor that facilitates trade cooperation between these countries. According to some studies, in addition to the potential exchange of products from extractive industries, there is a good potential to increase cooperation in several sectors, including horticulture sector and food processing. Kosovo and Albania imports consist mainly of consumer goods, while the share of imports in these respective economies remains insignificant compared to the potential significantly. Specifically, the products and services that can be traded and also have a comparative advantage due to short geographical distance should be used to the full.

A specific sector which requires immediate attention and which results from the interference is observed impromptu energy sector, especially that of transmission. Integrating power system between two states represents a potential source for increasing trade exchange. Albania and Kosovo currently sell excess energy produced in poor conditions of the market, while importing energy at very high prices. On the other hand, by making available Shëngjini port, the results could be felt in a relatively short period. This would enable Kosovo to improve trade ties with countries in the region and beyond, but will indirectly strengthen ties with the Albanian enterprises.

\section{The Prospect of Economic Relations between Kosovo and Albania. What is the Kosovo Government's Vision for the Future of the Country? What does Kosovo to other Countries and Albania?}

Reasons to Invest in Kosovo-The benefits to potential foreign investors and governments. Some of the benefits when you invest in Kosovo are: low taxes, rich resources and supportive business environment.

- Taxes in Kosovo are very low compared to neighboring countries.

- The tax system is kept extremely simple.

- Population-young and motivated, $70 \%$ under the age of 35

- A new power and motivated workforce with strong spirit and entrepreneurial skills and also general knowledge of most European languages

- Enviable natural resources: lignite, zinc, lead, ferro-nickel and fertile agricultural land.

- Free access to the EU market and neighboring markets

- Institutions modern business support

- Procedure simpler and faster for business registration (within 3 days)

- The banking system safe

- Modern legal structure and in accordance with the EU, and The official currency in Kosovo is the Euro, which eliminates the risk of the euro-zone.

After the declaration of independence, Kosovo has made significant progress in many areas of its development as: increasing political stability, raising the level of security, continued economic growth, etc. supplement legislation. It has become an important part of initiatives eg ional cooperation, which is achieved through the creation of a regional common market, the elimination of customs tariffs, the elimination of trade barriers and open new perspectives.

It created a stable macroeconomic environment, stable financial system, have become fiscal policy reforms in applying lower tax rates in the region.

Progress in the establishment of modern infrastructure, both within Kosovo and also in connection with the region, it is worth noting here the link with Albania highway built and commitments to Albania in a near future to build the railway line connecting these two countries. The importance of this route for Kosovo has double meaning when we consider that Kosovo already has its Adriatic port through which it connects to shipping. Through this road connects Kosovo with its port with an interval of only two and a half hours.

Usiness registration system in Kosovo is another important factor in the growth of investment incentives, with simplified procedures, speed and new businesses registering for a short time.

All these distinguishing Kosovo as an attractive investment opportunities for each investor to different sectors, as already expected privatization where privatization and concession granting of public companies as Post and Telecom of Kosovo and Distribution System Electricity as well as investment in green fields, in which very favorable opportunities in 
providing infrastructure provide industrial parks. Kosovo is working on creating financial capital market, in which investors would find who want to invest in shares of various companies. During 2012 is estimated to be invested $€ 232$ million, the total number of foreign companies operating in Kosovo amounts to about 5018. Investment banking system pose greater financial value to foreign capital. Foreign capital has a wide geographical distribution, from the 80 countries of the world, where Albania is ranked first for the number of registered businesses.

Advantages of the Kosovo economy in the investment field.

- VAT is $15 \%$

- Taxes on personal income ranges from $0-20 \%$

- 0 \% VAT or customs for export

- Taxes on corporate income $20 \%$

- Law on Foreign Investment

- Population - young and motivated, $70 \%$ under the age of 35 .

- Flexible workforce, low taxes on personal income. Mandatory contribution to individual pension is only 10.

- The euro is the official currency.

- Unused natural resources - coal, lead, zinc, ferronickel and fertile agricultural land.

- The banking system safe

- Energy and Mining

- Free access to the EU market and CEFTA.

- Stimulating environment for investment - Kosovo's institutional environment supports businesses:

- Free access to the EU market and neighboring markets

- Modern institutions to support businesses

- Procedure simpler and faster for business registration (within 3 days)

- Modern legal framework and in accordance with the EU, and

- Kosovo's official currency is the Euro, which eliminates the risk of exchange rate on the Euro - Zone.

Modern legislation for foreign investment - in particular, Kosovo has modern legislation for foreign investment, as provided for domestic investors as well as foreigners. This includes measures such as handling state guarantees for the use of revenue without limitation, prohibition of favoritism and discrimination and also protection against expropriation.

Kosovo's geographical position - central position in the region makes Kosovo a very advantageous to invest. Kosovo is positioned between the potential market in South East Europe. Kosovo is well connected with regional centers with road, rail and air communications. The Republic of Kosovo is linked to regional centers with 16 roads that pass through Kosovo.

Economic Initiative for Kosovo - ECIKS is a non-profit organization founded in Vienna, Austria in April 2003. ECIKS main goal is to support the economic development of Kosovo, mainly through foreign investment promotion acting independently or in within projects funded by donors.

What does Albania to the world and economy in particular? Registration of business: Since 2007, business registration done in one day at the National Registration Centre (NRC) for less than 1 euro and the number of steps for starting a new business is reduced from ten to five days.

- Licensing Procedures: Procedures for licensing in various sectors of the economy are simplified by creating the Business Licensing Center, in July, 2010.

- Public procurement: Public procurement have improved significantly in recent years. In order to improve the efficiency and transparency as well as strengthening the rule of law state.

- Taxes: Tax reform has contributed to the modernization and improvement of tax regime, improved collections and reduced the space for discretion and tax evasion. Tax policy is based on the philosophy of lower taxes and increasing the range of taxpayers.

- Trade policy: A proper trade policy facilitates the integration of the Albanian economy in Eastern Europe regional markets that can compensate the fact that Albania is a small country, opening for service delivery perspective. Among the instruments used to facilitate investment in the country's industrial parks and free zones, the creation of which is initiated by the Albanian government. Actually Parks are designated $7 /$ Industrial Zone concession, which are in the initial stages. These parks/area can be invested, managed by different investors through cooperative agreement or transfer.

- Development of transport infrastructure in the country is another priority objective of the Albanian government. In 1993, Albania adopted a legal framework for foreign direct investments that later mutated. The main features of 
the current investment regime are:

The economy is open - Our economy is open to all investors. No prior authorization is required for investment. As a rule, all sectors are open to foreign investment. The law guarantees equal treatment and fair. Investments by foreign investors and trekked home are allowed under the same conditions.

Do nationalization of foreign investment - Foreign Investment Law stipulates that foreign investments can not be nationalized or expropriated, except for special cases determined by law and when it is in the public interest. In these cases, the procedures should be conducted without discrimination and with compensation equal to the fair market value.

Protection by law of foreign investors - Investors in Albania are entitled to protection by the court of their rights related to their investments. Parties to a dispute may agree to submit disputes to arbitration institution consideration to.

Unrestricted ownership - Foreign investment enterprises registered in Albania as legal entities are allowed to own any land. Employment of foreign nationals also. Companies that invest in Albania are entitled to employ foreign nationals.

Free Transfer of funds - Associated with investment funds may be transferred abroad, in a freely convertible currency at the exchange rate calculated on actual transactions, on the date of the transfer.

Owever, the transfer of these funds may be restricted for non-payment of taxes or not obligations, as well as by the decisions of the courts.

Legislation - Albanian legislation every day more and more fit European standards and the World Trade Organization- And what we're looking for a long time, is to create a warm climate with regard to foreign investment.

\section{Conclusions}

1. Economy of Kosovo is a relatively new economy in terms of its own commitment in relation to other countries of the region and the world. Such as internal reserves in terms of its growth.

2. This economy is not yet a mature economy with European features and as such is not susceptible of phenomena that characterized the European economy in general. Although small economy and country border with Albania, with a common language and tradition it has not been very connected with this economy.

3. League of Kosovo with the Albanian economy is apparent only in recent years showed the same way as the data presented in the above materials. It is for this reason that we draw the conclusion that the Kosovo economy and has had a positive impact on the Albanian economy during 2009 following period. Kosovo factor has had a significant impact on our economy, particularly in the Kosovo War.

\section{Recommendations}

1. Ability to improve economic, social and political development between Kosovo and the region's countries, mainly Albania, will depend on the extent of use of its resources in the coming years. This requires reform of each party in the context of improving the conditions for cooperation.

2. Both belong economies emerging economies, which are assumed to have unused capacity. EU membership is another challenge of the two countries cial premises for continued efforts to achieve the standards of this union.

3. Kosovo and Albanian economy and it should have a higher level of engagement in all sectors of the economy by exploiting competitive advantages that each party presents.

4. For a long time, guarantee the success of the development of these reforms in Kosovo and Albania, will be to cooperate with the international community and the international financial and economic institutions

\section{References}

The Open Data Albania. Foreign Direct Investment in Albania By Country of Origin 2005-2010.

Report on Foreign Direct Investment in Kosovo, 2011.Maj 2012.UNCTAD.

Statistical Report, 2008, 2009, 2010, 2011, 2012, May 2013. Bank of Albania.

Journal of Economic Transition, Prof. Dr. Anastas Angeli, $p 793$.

Central Bank of the Republic of Kosovo (www.bqk - kos.org).

Economy of Kosovo (Wikipedia).

Bank of Albania (www.bankofalbania.org).

Www.mfa - ks.net

Www.mei - ks.net

Www.koha.net 